\title{
Supporting Information of Substituent-directed Structural and Physicochemical Controls of Diruthenium Catecholate Complexes with Ligand-unsupported Ru-Ru Bonds
}

\author{
Ho-Chol Chang, Katsunori Mochizuki, and Susumu Kitagawa*
}

Contribution from the Department of Synthetic Chemistry and Biological Chemistry, Graduate School of Engineering, Kyoto University, Katsura, Nishikyo-ku, Kyoto 615-8510, Japan

Received XXXX, 2004; E-mail: kitagawa@ sbchem.kyoto-u.ac.jp; chang@sbchem.kyoto-u.ac.jp

* Corresponding author. Tel: +81-75-383-2733. Fax: +81-75-383-2732.

\section{Contents}

Synthetic procedures of the complexes

Description of individual crystal structures

Figure S1. Temperature dependent magnetic susceptibility of $\left[\mathrm{Na}_{3}\left\{\mathrm{Ru}_{2}\left(\mathrm{R}_{4} \mathrm{Cat}\right)_{4}\right\}\right]\left(\mathrm{R}_{4}=-\mathrm{F}_{4}(\mathbf{1})\right.$, $-\mathrm{Cl}_{4}(\mathbf{2}),-\mathrm{Br}_{4}(\mathbf{3})$, and $\left.-\mathrm{H}_{4}(\mathbf{4})\right)$.

Figure S2. EPR spectra of $\left[\mathrm{Na}_{3}\left\{\mathrm{Ru}_{2}\left(\mathrm{R}_{4} \mathrm{Cat}\right)_{4}\right\}\right]\left(\mathrm{R}_{4}=(\mathrm{a})-\mathrm{F}_{4}(\mathbf{1}\right.$ in THF $),(\mathrm{b})-\mathrm{Cl}_{4}(\mathbf{2}$ in THF), (c) $-\mathrm{Br}_{4}\left(3\right.$ in THF), and (d) $-\mathrm{H}_{4}(\mathbf{4}$ in DMF)) at $77 \mathrm{~K}$.

Figure S3. Seven possible isomers for $\left[\mathrm{Ru}_{2}(3,5-\mathrm{DTBCat})_{4}\right]^{2-}$.

Figure S4. ${ }^{1} \mathrm{H}-\mathrm{NMR}$ spectrum of $\mathbf{5}$ ' measured in DMF- $d_{7}$ at $25^{\circ} \mathrm{C}$.

Figure S5. Absorption spectra of $\left[\mathrm{Na}_{3}\left\{\mathrm{Ru}_{2}\left(\mathrm{R}_{4} \mathrm{Cat}\right)_{4}\right\}\right]\left(\mathrm{R}_{4}=-\mathrm{F}_{4}\left(\mathbf{1}\right.\right.$ in THF), $-\mathrm{Cl}_{4}(\mathbf{2}$ in THF), $-\mathrm{Br}_{4}\left(3\right.$ in THF), and $-\mathrm{H}_{4}(\mathbf{4}$ in DMF $)$ ).

Figure S6. Absorption spectra of $\left[\mathrm{Na}_{2}\left\{\mathrm{Ru}_{2}\left(\mathrm{R}_{4} \mathrm{Cat}\right)_{4}\right\}\right]\left(\mathrm{R}_{4}=-\mathrm{F}_{4}\left(\mathbf{1}^{\prime}\right),-\mathrm{Cl}_{4}\left(\mathbf{2}^{\prime}\right),-\mathrm{Br}_{4}\left(\mathbf{3}^{\prime}\right),-\mathrm{H}_{4}\right.$ $\left(\mathbf{4}^{\prime}\right)$, 3,5-DTB (5'), and 3,6-DTB $\left.\left(\mathbf{6}^{\prime}\right)\right)$ in THF. 


\section{Synthetic procedures of the complexes}

$\left[\mathbf{N a}_{3}\left\{\mathbf{R u}_{2}\left(\mathbf{F}_{4} \mathbf{C a t}\right)_{4}\right\}\right] \cdot \mathbf{2} \mathbf{T H F} \cdot \mathbf{2} \mathbf{H}_{2} \mathrm{O}(\mathbf{1}) \quad \mathrm{Ru}_{2}(\mathrm{OAc})_{4} \mathrm{Cl}(119 \mathrm{mg}, 0.25 \mathrm{mmol}), \mathrm{F}_{4} \mathrm{CatH}_{2}(182 \mathrm{mg}, 1.00$ mmol), and $\mathrm{NaOH}(80 \mathrm{mg}, 2.00 \mathrm{mmol}$ ) were combined in THF to afford the dark violet polycrystalline sample. Yield: $211 \mathrm{mg}(72 \%)$. Anal. Calcd. for $\mathrm{C}_{32} \mathrm{H}_{20} \mathrm{~F}_{16} \mathrm{Na}_{3} \mathrm{O}_{12} \mathrm{Ru}_{2}$ (1): C, 32.81; H, 1.72. Found: C, 32.91; H, 1.94. Paramagnetic: $\mu_{\text {eff }}=1.28$ (2 K) and 1.67 B. M. (300 K).

$\left[\mathbf{N a}_{3}\left\{\mathbf{R u}_{2}\left(\mathbf{B r}_{4} \mathbf{C a t}\right)_{4}\right\}\right] \cdot \mathbf{4 T H F} \cdot \mathbf{2} \mathbf{H}_{2} \mathbf{O}(\mathbf{3}) \quad \mathrm{Ru}_{2}(\mathrm{OAc})_{4} \mathrm{Cl}(119 \mathrm{mg}, 0.25 \mathrm{mmol}), \mathrm{Br}_{4} \mathrm{CatH}_{2}(426 \mathrm{mg}, 1.00$ mmol), and $\mathrm{NaOH}(80 \mathrm{mg}, 2.00 \mathrm{mmol}$ ) were combined in THF to afford the dark violet crystals. The polycrystalline sample formulated as $\left[\mathrm{Na}_{3}\left\{\mathrm{Ru}_{2}\left(\mathrm{Br}_{4} \mathrm{Cat}\right)_{4}\right\}\right] \cdot 4 \mathrm{THF} \cdot 2 \mathrm{H}_{2} \mathrm{O}$ was obtained by drying the single crystals under vacuum. Yield: $492 \mathrm{mg}$ (86\%). Anal. Calcd. for $\mathrm{C}_{40} \mathrm{H}_{36} \mathrm{Br}_{16} \mathrm{Na}_{3} \mathrm{O}_{14} \mathrm{Ru}_{2}$ (3): C, 20.98; H, 1.58. Found: C, 20.82; H, 1.50. A single crystal for X-ray crystallographic data collection ([Na $\left.\left\{\mathrm{Na}(\text { acetone })\left(\mathrm{H}_{2} \mathrm{O}\right)\right\}_{2}\left\{\mathrm{Ru}_{2}\left(\mathrm{Br}_{4} \mathrm{Cat}\right)_{4}\right\}\right] \cdot 2$ acetone $\left.\left(\mathbf{3}_{\mathrm{s}}\right)\right)$ was obtained by slow diffusion of hexane onto the acetone solution of 3. Paramagnetic (3) : $\mu_{\text {eff }}=0.99(2 \mathrm{~K})$ and 1.63. M. (300 K).

$\left[\mathbf{N a}\{\mathbf{N a}(\mathbf{D M F})\}_{2}\left\{\mathbf{R u}_{2}\left(\mathbf{H}_{4} \mathbf{C a t}\right)_{4}\right\}\right](4) \quad \mathrm{Ru}_{2}(\mathrm{OAc})_{4} \mathrm{Cl}(237 \mathrm{mg}, 0.50 \mathrm{mmol}), \mathrm{H}_{4} \mathrm{CatH}_{2}(220 \mathrm{mg}, 2.00$ mmol), and $\mathrm{NaOH}(160 \mathrm{mg}, 4.00 \mathrm{mmol})$ were combined in THF to afford the red microcrystals of 4. Yield: $305 \mathrm{mg}$ (72\%). Anal. Calcd. for $\mathrm{C}_{30} \mathrm{H}_{30} \mathrm{~N}_{2} \mathrm{Na}_{3} \mathrm{O}_{10} \mathrm{Ru}_{2}$ (4): C, 42.41; H, 3.56; N, 3.30. Found: C, 41.95; H, 3.36; N, 3.24. Paramagnetic: $\mu_{\text {eff }}=1.30(2 \mathrm{~K})$ and 1.66. M. (300 K).

$\left[\left\{\mathbf{N a}(\mathbf{D M E})_{2}\right\}_{2}\left\{\mathbf{R u}_{2}(\mathbf{3 , 5}-\mathrm{DTBCat})_{4}\right\}\right]\left(\mathbf{5}^{\prime}\right) \quad \mathrm{Ru}_{2}(\mathrm{OAc})_{4} \mathrm{Cl}(119 \mathrm{mg}, 0.25 \mathrm{mmol}), 3,5-\mathrm{DTBCatH} \mathrm{H}_{2}(222$ $\mathrm{mg}, 1.00 \mathrm{mmol})$, and $\mathrm{NaOH}(80 \mathrm{mg}, 2.00 \mathrm{mmol})$ were combined in THF to afford the reddish-purple crystals of 5'. Yield: $197 \mathrm{mg}(53 \%)$. Anal. Calcd. for $\mathrm{C}_{72} \mathrm{H}_{120} \mathrm{Na}_{2} \mathrm{O}_{16} \mathrm{Ru}_{2}\left(\mathbf{5}^{\prime}\right)$ : C, 58.04; H, 8.12. Found: C, 58.03; H, 7.99. Diamagnetic.

$\left[\mathbf{N a}_{2}\left\{\mathbf{R u}_{2}(\mathbf{3 , 6}, \mathrm{DTBCat})_{4}\right\}\right]\left(\mathbf{6}^{\prime}\right) \quad \mathrm{Ru}_{2}(\mathrm{OAc})_{4} \mathrm{Cl}(237 \mathrm{mg}, 0.50 \mathrm{mmol}), 3,6-\mathrm{DTBCatH} \mathrm{H}_{2}(445 \mathrm{mg}, 2.00$ $\mathrm{mmol})$, and $\mathrm{NaOH}(160 \mathrm{mg}, 4.00 \mathrm{mmol})$ were combined in THF to afford the reddish-purple crystals of $\left[\left\{\mathrm{Na}(\mathrm{THF})_{2}\right\}\left\{\mathrm{Ru}_{2}(3,6-\mathrm{DTBCat})_{4}\right\}\right]\left(\mathbf{6}_{\mathrm{s}}{ }_{\mathrm{s}}\right)$. A s\$rigle crystal easily loses the cocrystallized solvents 
of $\left[\left\{\mathrm{Na}(\mathrm{THF})_{2}\right\}\left\{\mathrm{Ru}_{2}(3,6-\mathrm{DTBCat})_{4}\right\}\right]\left(\mathbf{6}_{\mathrm{s}}{ }^{\prime}\right)$. A single crystal easily loses the cocrystallized solvents under vacuum. The polycrystalline sample formulated as $\left[\mathrm{Na}_{2}\left\{\mathrm{Ru}_{2}(3,6-\mathrm{DTBCat})_{4}\right\}\right]$ was obtained by drying the single crystals under vacuum. Yield: $350 \mathrm{mg}$ (62\%). Anal. Calcd for $\mathrm{C}_{56} \mathrm{H}_{80} \mathrm{Na}_{2} \mathrm{O}_{8} \mathrm{Ru}_{2}\left(6^{\prime}\right): \mathrm{C}, 59.56 ; \mathrm{H}, 7.14$. Found: C, 58.99; H, 7.69. Diamagnetic.

$\left[\mathbf{N a}_{2}\left\{\mathbf{R u}_{\mathbf{2}}\left(\mathbf{F}_{\mathbf{4}} \mathbf{C a t}\right)_{4}\right\}\right] \cdot \mathbf{3 T H F}(\mathbf{1}) \quad \mathbf{1}(117 \mathrm{mg}, 0.10 \mathrm{mmol})$ and $\operatorname{AgOCOCF}_{3}(22.1 \mathrm{mg}, 0.10 \mathrm{mmol})$ were combined in THF to afford the dark violet powder of 1'. Yield: $47 \mathrm{mg}(40 \%)$. Anal. Calcd. for $\mathrm{C}_{36} \mathrm{H}_{24} \mathrm{~F}_{16} \mathrm{Na}_{2} \mathrm{O}_{11} \mathrm{Ru}_{2}\left(\mathbf{1}^{\prime}\right): \mathrm{C}, 36.50 ; \mathrm{H}, 2.04$. Found: $\mathrm{C}, 36.18 ; \mathrm{H}, 2.27$. Diamagnetic.

$\left[\mathbf{N a}_{2}\left\{\mathbf{R u}_{2}\left(\mathbf{B r}_{4} \mathbf{C a t}\right)_{4}(\mathbf{T H F})_{2}\right\}\right] \cdot \mathbf{3 T H F}\left(\mathbf{3}^{\prime}\right) \quad \mathbf{3}(229 \mathrm{mg}, 0.10 \mathrm{mmol})$ and $\mathrm{AgOCOCF}_{3}(22.1 \mathrm{mg}, 0.10$ mmol) were combined in THF to afford dark violet crystals of $\left[\left\{\mathrm{Na}(\mathrm{THF})_{2}\right\}_{2}\left\{\mathrm{Ru}_{2}\left(\mathrm{Br}_{4} \mathrm{Cat}\right)_{4}(\mathrm{THF})_{2}\right\}\right]$ $\left(\mathbf{3}_{\mathrm{s}}\right)$. The single crystal easily loses the cocrystallized solvent under vacuum. The polycrystalline sample formulated as $\left[\mathrm{Na}_{2}\left\{\mathrm{Ru}_{2}\left(\mathrm{Br}_{4} \mathrm{Cat}\right)_{4}(\mathrm{THF})_{2}\right\}\right] \cdot 3 \mathrm{THF}$ was obtained by drying the single crystals under vacuum. Yield: $194 \mathrm{mg}(86 \%)$. Anal. Calcd. for $\mathrm{C}_{44} \mathrm{H}_{40} \mathrm{Br}_{16} \mathrm{Na}_{2} \mathrm{O}_{13} \mathrm{Ru}_{2}\left(3^{\prime}\right)$ : C, 22.94; $\mathrm{H}$, 1.75. Found: C, 23.22; H, 1.85. Diamagnetic.

$\left[\mathbf{N a}_{2}\left\{\mathbf{R u}_{2}\left(\mathbf{H}_{4} \mathbf{C a t}\right)_{4}\right\}\right] \cdot \mathbf{2 T H F}\left(\mathbf{4}^{\prime}\right) \mathbf{4}(85 \mathrm{mg}, 0.10 \mathrm{mmol})$ and $\mathrm{AgOCOCF}_{3}(22.1 \mathrm{mg}, 0.10 \mathrm{mmol})$ were combined in THF to afford violet powder of 4'. Yield: $62 \mathrm{mg}(75 \%)$. Anal. Calcd. for $\mathrm{C}_{32} \mathrm{H}_{32} \mathrm{Na}_{2} \mathrm{O}_{10} \mathrm{Ru}_{2}\left(4^{\prime}\right): \mathrm{C}, 46.60 ; \mathrm{H}, 3$.91. Found: C, 46.62; H, 4.09. Diamagnetic. 


\section{Description of individual crystal structures}

$\mathbf{2}_{\mathrm{s}}$ : The structure of the complex was reported in $1998 .^{6}$ The structure demonstrates the formation of a nearly ideal eclipsed form with the Ru-Ru bond distance, 2.273(1) A. One THF coordinates to the axial position of $\mathrm{Ru}(1)$, giving two different coordination environments to two independent $\mathrm{Ru}$ atoms (core structure II). The $\mathrm{Ru}(1)$ atom with the axial THF shows a slightly smaller $d$ value, $0.271(3) \AA$, compared with $0.363(3) \AA$ for the $\mathrm{Ru}(2)$ atom with the vacant axial site.

$\mathbf{3}_{\mathrm{s}}$ : No axial ligand has been found in $\mathbf{3}_{\mathrm{s}}$ similar to 4 . The $\mathrm{Ru}-\mathrm{Ru}$ bond distance of $\mathbf{3}_{\mathrm{s}}$ is slightly contracted compared with $\mathbf{2}_{\mathrm{s}}$. Because the size of $\mathrm{Br}$ atoms is larger than that of $\mathrm{Cl}$ atom, the $d$ values and $\mathrm{Ru}-\mathrm{Ru}-\mathrm{O}_{\mathrm{Cat}}$ angles are significantly enlarged. In addition, the large $\theta$ value of $\mathbf{3}_{\mathrm{s}}$ reflects interligand steric hindrance between the two $\mathrm{Br}_{4} \mathrm{Cat}^{2-}$ ligands.

4: The titled complex with $\mathrm{H}_{4} \mathrm{Cat}^{2-}$ ligands can be regarded as a standard for the comparison of the molecular structures of the complexes with substituted $\mathrm{Cat}^{2-} \mathrm{s}$. The $\mathrm{Ru}-\mathrm{Ru}$ bond distance is actually the shortest among the $\left[\mathrm{Na}_{3}\left\{\mathrm{Ru}_{2}\left(\mathrm{R}_{4} \mathrm{Cat}\right)_{4}\right\}\right]$ family, where the largest difference reaches $c a$. $0.05 \AA$. The complex has two crystallographically independent dimers in the unit cell, and both have an eclipsed form with the $d$ values, $0.373(3)$ and $0.388(3) \AA$, for dimer $\mathbf{i}$ and ii, respectively. Since dimer ii has the shortest $\mathrm{Ru}-\mathrm{Ru}$ bond distance, the $d$ values become larger than those of the others.

$\mathbf{2}_{\mathrm{s}}$ : The structure of the complex was reported by our group in $1998 .{ }^{6}$ The complex maintains the eclipsed form during the one-electron oxidation process, and has the longest $\mathrm{Ru}-\mathrm{Ru}$ bond in the $\left[\mathrm{Na}_{2} \mathrm{Ru}_{2}\left(\mathrm{R}_{4} \mathrm{Cat}\right)_{4}\right]$ family, while it is shorter than those of any complexes in the $\left[\mathrm{Na}_{3} \mathrm{Ru}_{2}\left(\mathrm{R}_{4} \mathrm{Cat}\right)_{4}\right]$ family (Table 2).

$\mathbf{3}_{\mathrm{s}}$ : The $\mathrm{Ru}-\mathrm{Ru}$ bond distance of the complex is slightly shortened by $0.03 \AA$ compared with $\mathbf{2}_{\mathrm{s}}$. The $\theta$ value drastically increases in $\mathbf{3}{ }_{\mathrm{s}}$ compared with 2 , ${ }_{\mathrm{s}}$, reflecting the greater size of the 
bromine substituents.

5': The asymmetric structure of 3,5-DTBCat ${ }^{2-}$ allows the formation of seven different metal-metal bonded isomers (Figure S3). Among the possible isomers, the obtained structure is (b) cis,cis-anti form, as drawn in Figures $2 \mathrm{e}$ and $2 \mathrm{f}$. The centrosymmetric dianion of $\mathbf{5}$ ' has two 3,5-DTBCat ${ }^{2-}$ ligands coordinating to the $\mathrm{Ru}$ atom in cis-fashion in one-half of the dimer, [Ru(3,5-DTBCat $\left.)_{2}\right]$. The two halves adopt an eclipsed configuration so that each $-t$-Bu substituent tends to avoid the other. We tried to mount several crystals with different morphologies, however, these attempts repeatedly gave the same unit cell parameter as that tabulated in Table 1ut did not give any different crystal systems. In addition, the coordination of the $\mathrm{Na}^{+}$cations to the anionic dimer would greatly contribute to the structural rigidity of the eclipsed combination of two cis-configurated $[\mathrm{Ru}(3,5-$ DTBCat $)_{2}$ ] halves. These facts suggest that the formation of other structural isomers would be excluded under the conditions used for the isolation of 5' (see the NMR spectrum (Figure S4) measured in DMF- $d_{7}$ at $25^{\circ} \mathrm{C}$ for $\mathbf{5}$ ', which could be derived from only one isomeric form).

6' ${ }_{\mathrm{s}}$ : The Ru-Ru bond distance of the complex shows the shortest value, 2.140(2) $\AA$, and the largest deviation, $d=0.509(5) \AA$, among the structurally characterized complexes. The complex is forced to rotate around the $\mathrm{Ru}-\mathrm{Ru}$ bond axis by the presence of $-t-\mathrm{Bu}$ substituents on the 3- and 6- positions so that each $-t$-Bu substituent avoids each other. Consequently, the $\theta$ value attains the largest value, $50.8^{\circ}$ 


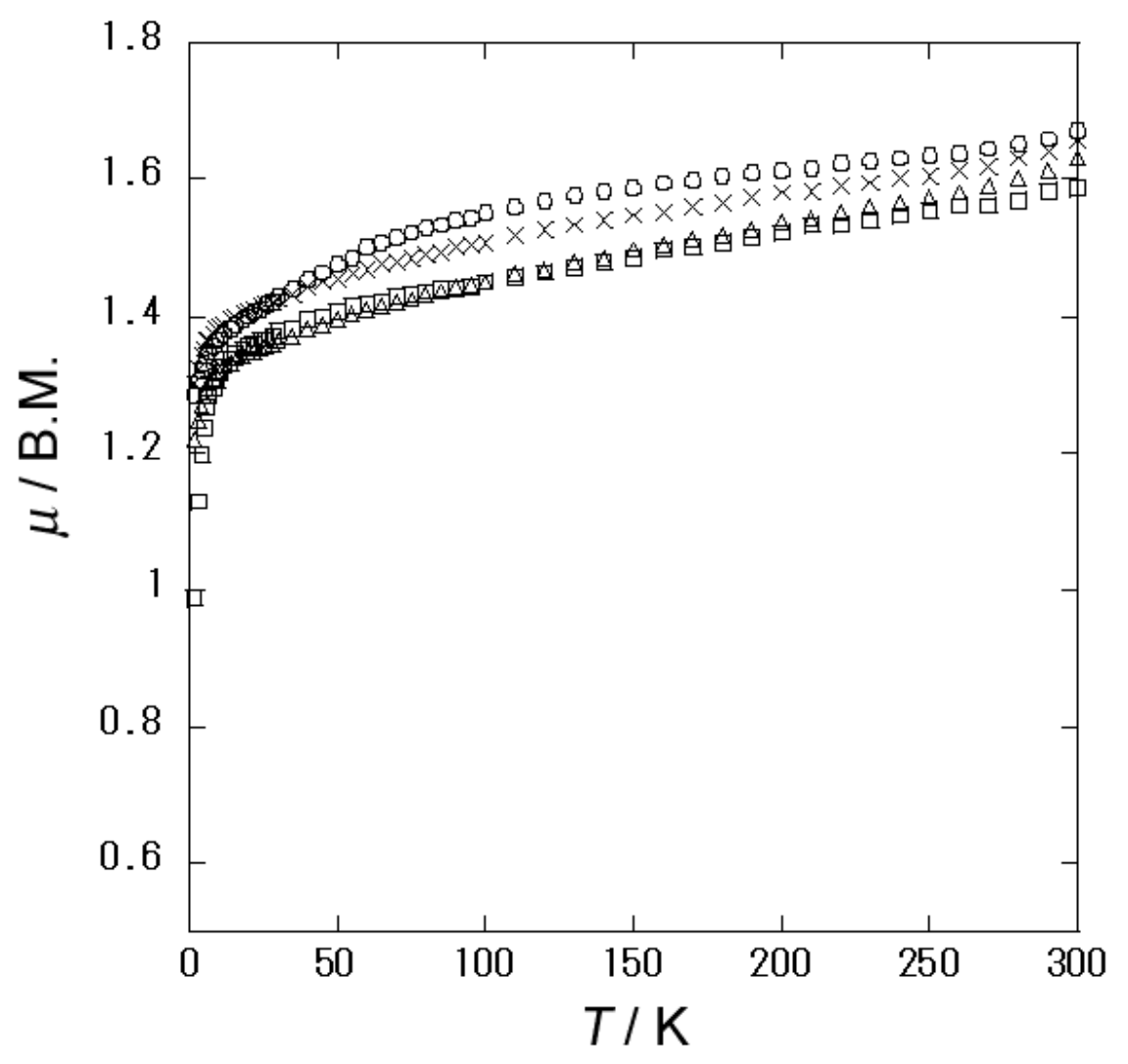

Figure S1. Temperature dependent magnetic susceptibility of $\left[\mathrm{Na}_{3}\left\{\mathrm{Ru}_{2}\left(\mathrm{R}_{4} \mathrm{Cat}\right)_{4}\right\}\right]\left(\mathrm{R}_{4}=-\mathrm{F}_{4}(\mathbf{1}\right.$ $(\bigcirc)),-\mathrm{Cl}_{4}(\mathbf{2}(\square)),-\mathrm{Br}_{4}(\mathbf{3}(\triangle))$, and $\left.-\mathrm{H}_{4}(\mathbf{4}(\times))\right)$. 
(a)

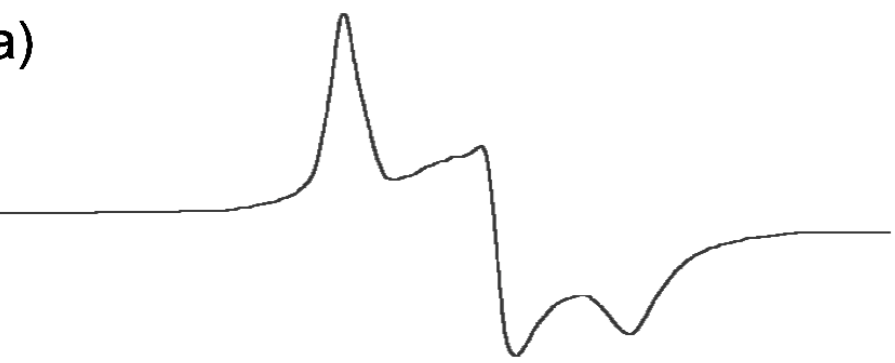

(b)

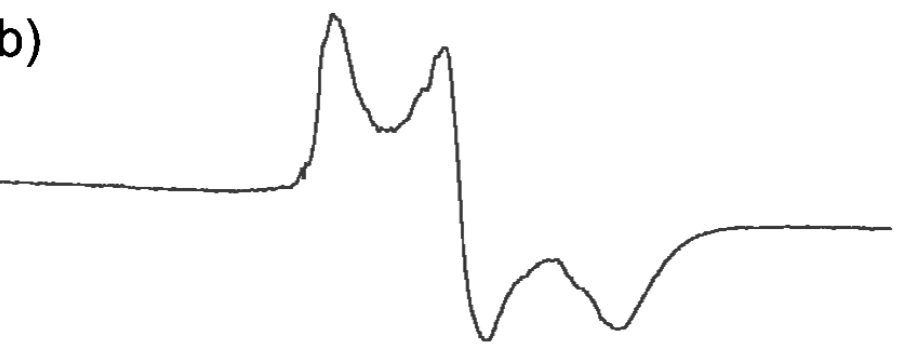

(c)
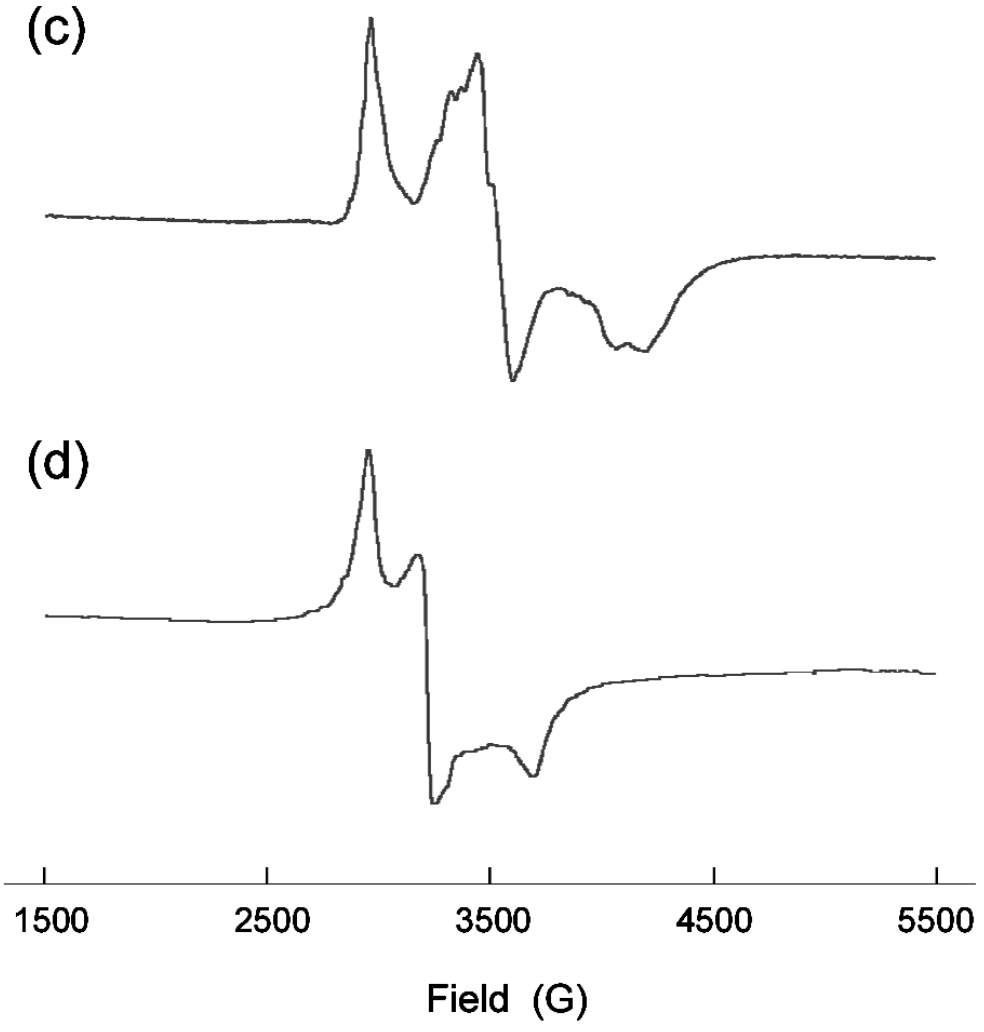

Figure S2. EPR spectra of $\left[\mathrm{Na}_{3}\left\{\mathrm{Ru}_{2}\left(\mathrm{R}_{4} \mathrm{Cat}\right)_{4}\right\}\right]\left(\mathrm{R}_{4}=(\mathrm{a})-\mathrm{F}_{4}\left(\mathbf{1}\right.\right.$ in THF), (b) $-\mathrm{Cl}_{4}(\mathbf{2}$ in THF), (c) $-\mathrm{Br}_{4}\left(3\right.$ in THF), and (d) $-\mathrm{H}_{4}(4$ in DMF)) at $77 \mathrm{~K}$. Microwave frequency: $9.100 \mathrm{GHz}$ for $\mathbf{1}, 9.178$ $\mathrm{GHz}$ for $\mathbf{2}, 9.168 \mathrm{GHz}$ for $\mathbf{3}, 9.104 \mathrm{GHz}$ for 4 . 


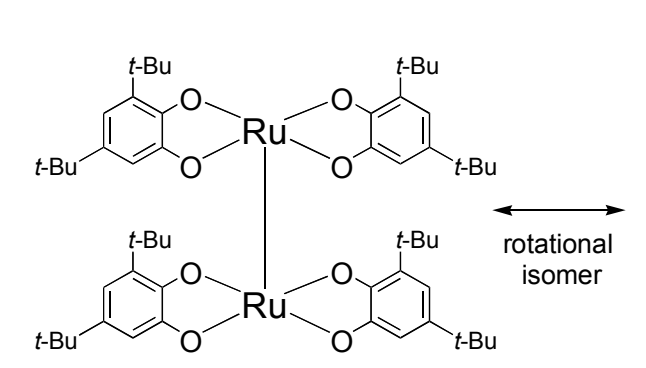

(a) cis, cis-syn
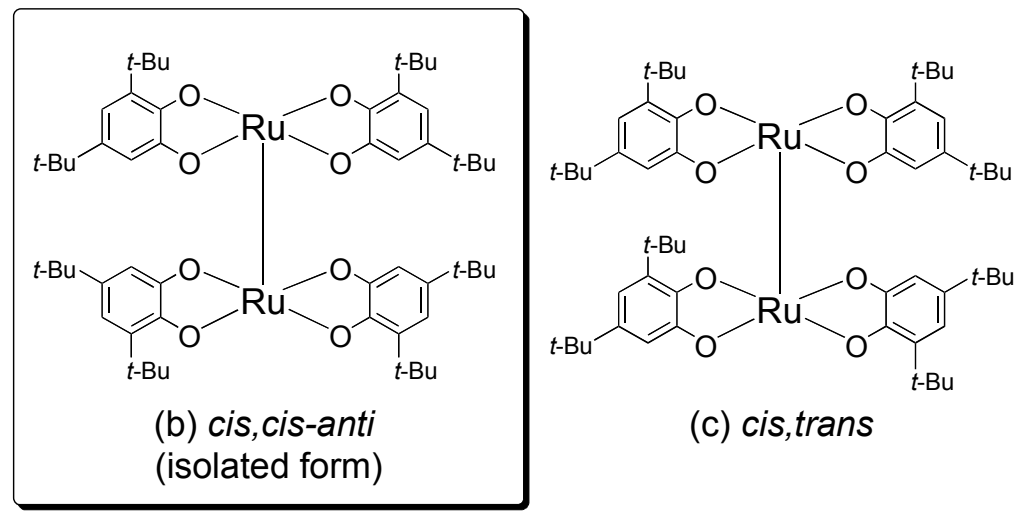

(c) cis,trans

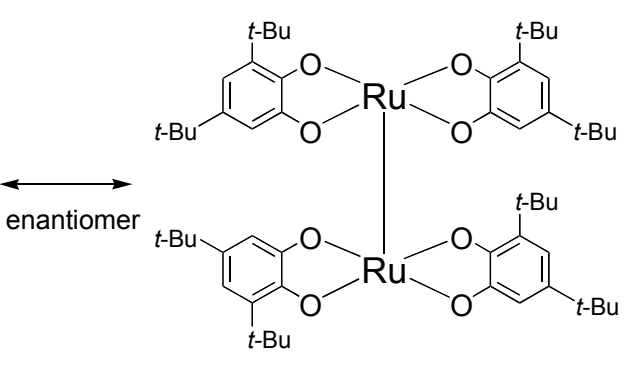

(d) cis,trans

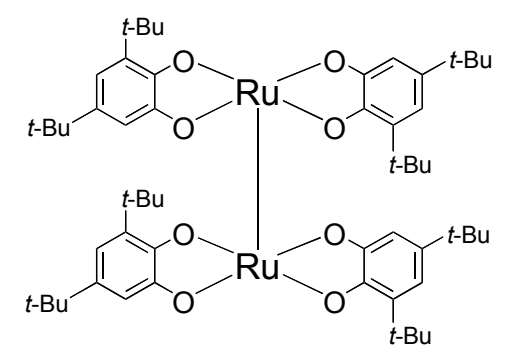

(e) trans,trans-syn

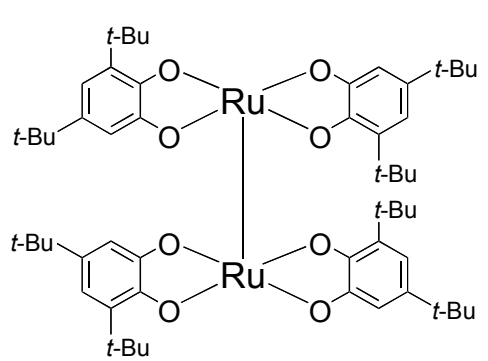

(f) trans,trans-anti

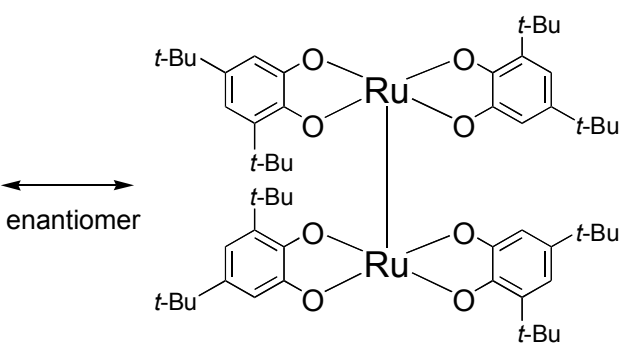

(g) trans, trans-anti

Figure S3. Seven possible isomers for $\left[\mathrm{Ru}_{2}(3,5-\mathrm{DTBCat})_{4}\right]^{2-}$. 

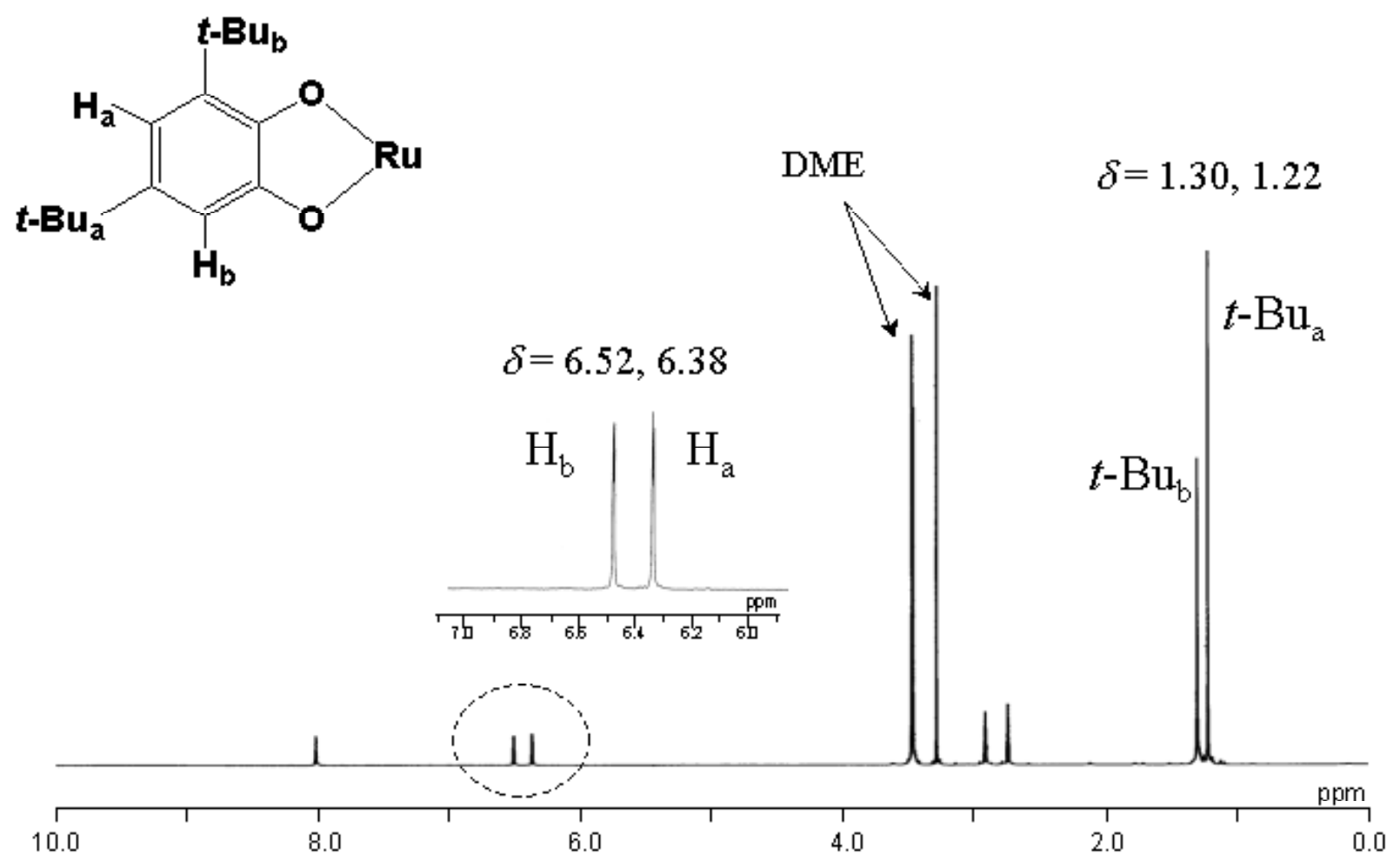

Figure S4. $\quad{ }^{1} \mathrm{H}-\mathrm{NMR}$ spectrum of 5' measured in DMF- $d_{7}$ at $25^{\circ} \mathrm{C}$. 


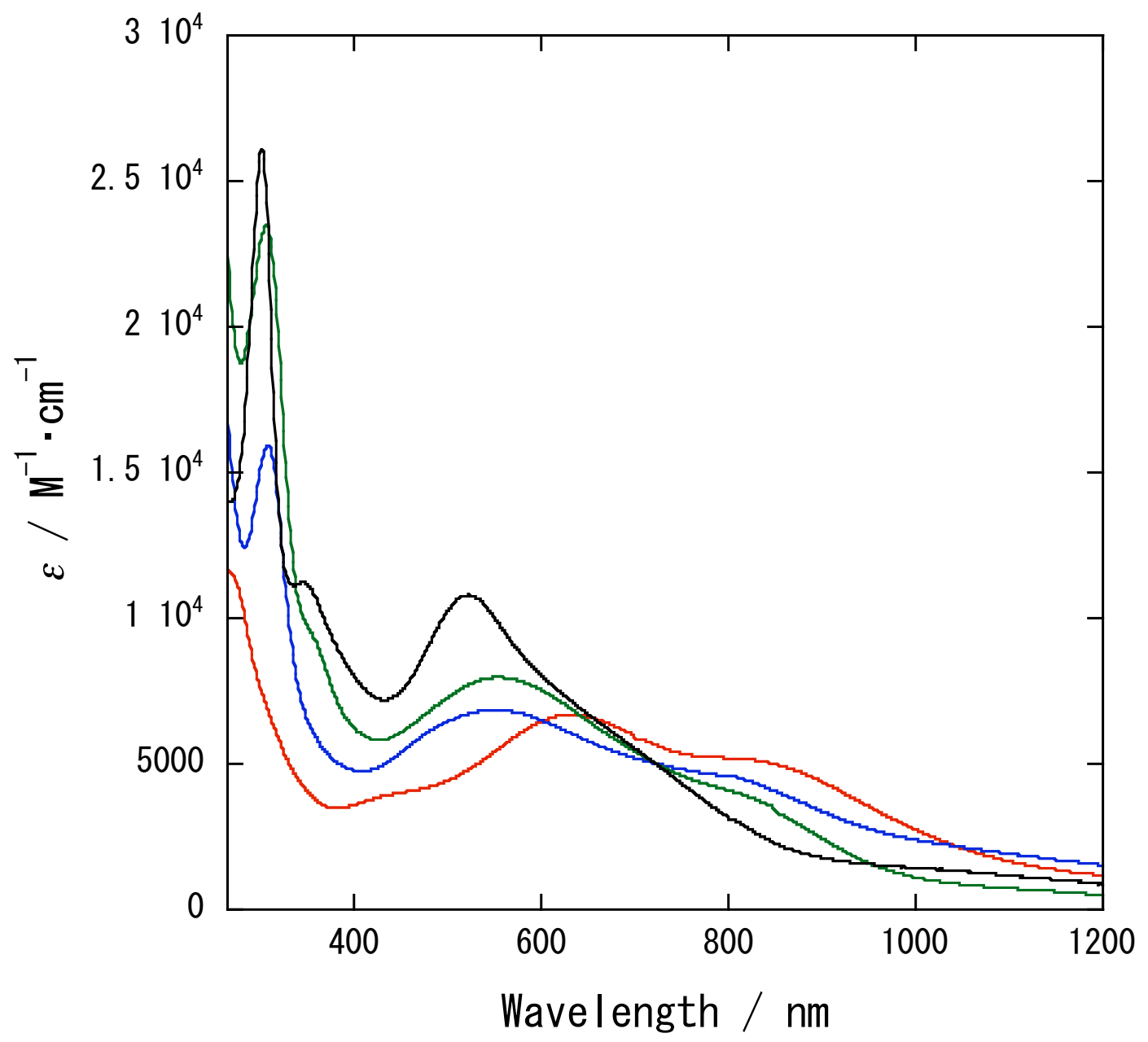

Figure S5. Absorption spectra of $\left[\mathrm{Na}_{3}\left\{\mathrm{Ru}_{2}\left(\mathrm{R}_{4} \mathrm{Cat}\right)_{4}\right\}\right]\left(\mathrm{R}_{4}=-\mathrm{F}_{4}\left(\mathbf{1}\right.\right.$ in THF, red line), $-\mathrm{Cl}_{4}(\mathbf{2}$ in THF, blue line), $-\mathrm{Br}_{4}\left(3\right.$ in THF, green line), and $-\mathrm{H}_{4}(4$ in DMF, black line)). 


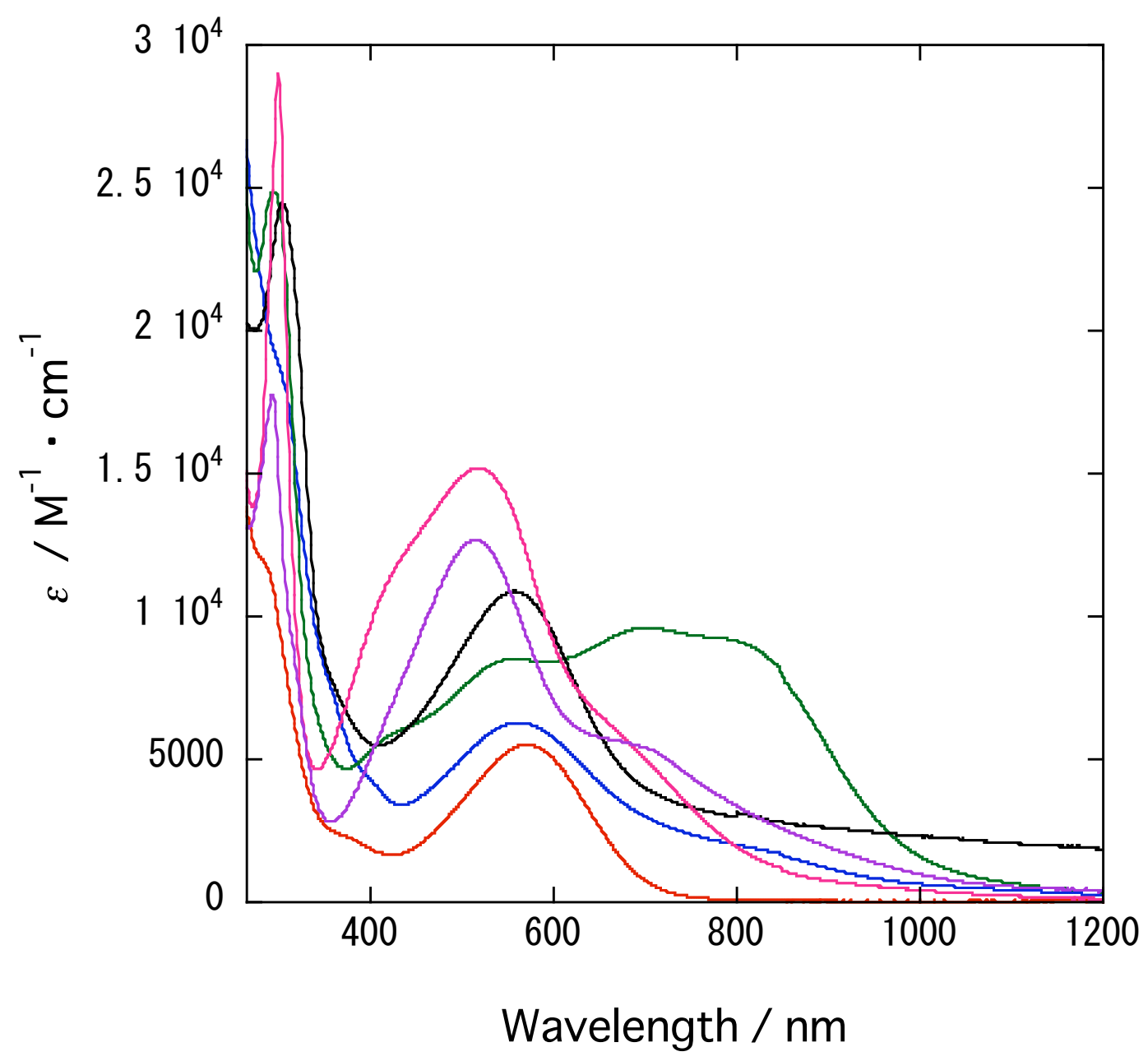

Figure S6. Absorption spectra of $\left[\mathrm{Na}_{2}\left\{\mathrm{Ru}_{2}\left(\mathrm{R}_{4} \mathrm{Cat}\right)_{4}\right\}\right]\left(\mathrm{R}_{4}=-\mathrm{F}_{4}(\mathbf{1}\right.$, red line $),-\mathrm{Cl}_{4}(\mathbf{2}$ ', blue line), $-\mathrm{Br}_{4}\left(\mathbf{3}^{\prime}\right.$, green line), $-\mathrm{H}_{4}\left(\mathbf{4}^{\prime}\right.$, black line), $-3,5-\mathrm{DTB}\left(\mathbf{5}^{\prime}\right.$, pink line), and -3,6-DTB (6', purple line)) in THF. 